\title{
Breaking the feed barrier using maize silage
}

R. DENSLEY ${ }^{1}$, D. MILLER ${ }^{1}$ and E.S. KOLVER ${ }^{2}$

${ }^{1}$ Genetic Technologies Ltd, P.O. Box 105 303, Auckland

${ }^{2}$ Dexcel, Private Bag 3123, Hamilton

rdensley@genetic.co.nz

\begin{abstract} strategies. Maize silage has proven to be a cost effective supplementary feed that allows farmers to achieve higher MS/ha production. The worldwide significance of maize ensures a large plant breeding and research input that has resulted in significant ongoing genetic gains. Current maize feeding systems are based around systems quantified and described by research at Waimate West Demonstration Farm. A number of new technologies using maize silage are being investigated. These centre on manipulating the feed value of the silage through both plant breeding mechanisms and harvest-management strategies.
\end{abstract}

This paper reviews the key factors that have led to the widespread adoption of maize silage in North Island and Canterbury dairying systems and explores current maize silage feeding

Keywords: maize silage, supplementary feed

\section{Introduction}

Milk production in pastoral dairy systems is limited by the amount of pasture that can be grown in a season. The potential annual net accumulation of dairy pasture drymatter (DM) has been estimated at 15-19 t/ha/year (Penno 1999). The average annual pasture production on research farms and top farms is around $15 \mathrm{t} \mathrm{DM} / \mathrm{ha}$ and this has not significantly increased in the last 40 years (Deane 1999). National statistics show an improvement in milksolids production/ha over the last 20 years, from $500 \mathrm{~kg} \mathrm{MS} / \mathrm{ha}$ in the 1980 to $762 \mathrm{~kg} \mathrm{MS} / \mathrm{ha}$ 1999/2000. (Livestock Improvement Corporation 2000) This improvement is a consequence of a number of factors including increased stocking rate, better cow genetic potential and improved management resulting in improved pasture utilisation. Data from research dairy farms which already had efficient systems in place, suggest they have reached a production ceiling (Figure 1). Maize silage is being utilised by an increasing number of farmers who are striving to increase profitability by moving through this feed barrier and lifting milk production levels.
Figure 1 Production parameters on the pasture-only farmlet (no N) at Ruakura № 2 Dairy since 1960 (Deane 1999).

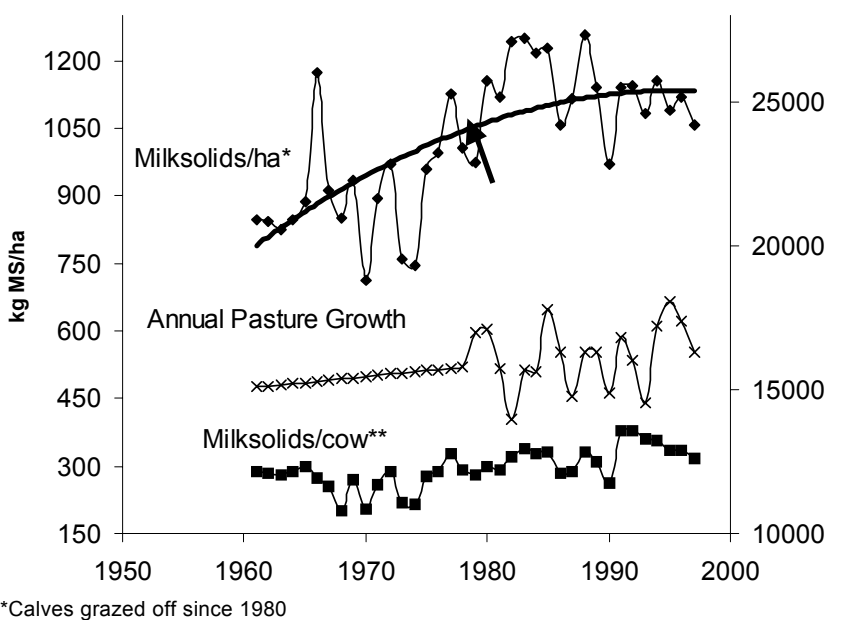

This paper reviews why the yield potential of maize silage has increased over the past 40 years. It reports average New Zealand maize silage yields for a range of current commercial hybrids. Currently, many farmers are buying in maize silage and this paper examines how they are using it. In the future, limitations to supply may make growing on-farm the most viable option. Using maize silage as part of an on-farm pasture renovation programme and the development of a continuous cropping system using maize silage and Italian ryegrass, are discussed.

\section{Maize silage yields}

While pasture yields have remained relatively stable, average New Zealand maize silage yields have almost trebled over the past 40 years (Figure 2). This increase in yield can be attributed to improved maize genetics and advanced management techniques. 
Figure $\llbracket 2$ Gains in Waikato pasture yield and New Zealand maize silage yields over the last 40 years (Deane1999).

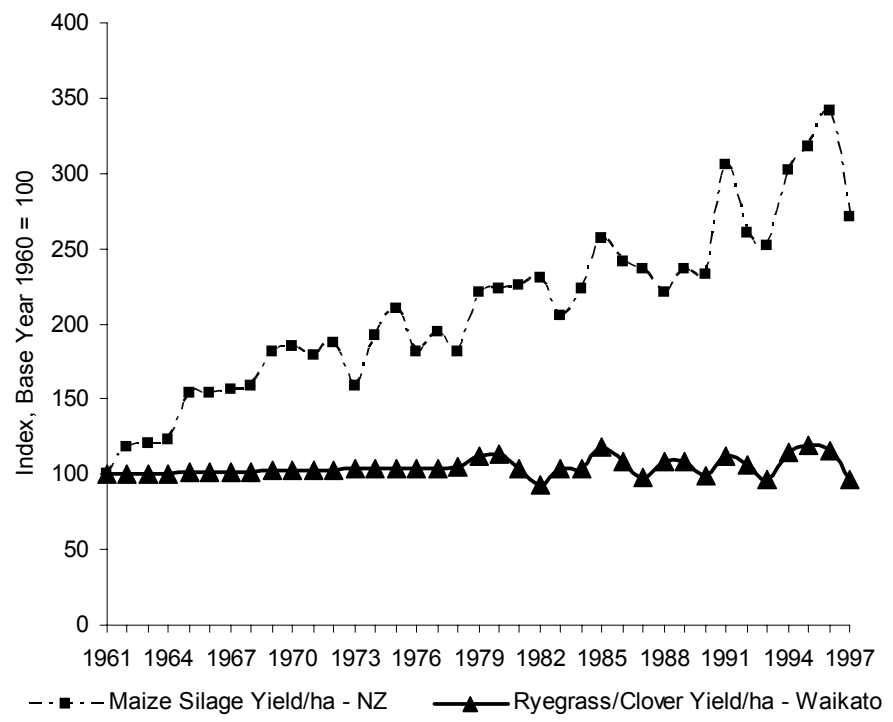

* Maize silage yield (tDM/ha) is assumed to be maize grain yield ( $/$ ha) $\times 1.8$. Maize grain yields obtained from The Statistical Yearbook (1961-1985) and from the Pioneer® brand grain yield evaluation programme 1986-1997

\section{Improved maize genetics}

Significant improvements in the genetic yield potential of maize hybrids have occurred in the last 70 years. In a study conducted in Wisconsin, USA during the 19971998 season, maize hybrids that were commercially released during the period 1900-1997 were planted side by side at three locations and yield and quality characteristics were compared. Since 1930, maize silage whole-plant drymatter yield has increased at the rate of 128 to $164 \mathrm{~kg} \mathrm{DM} /$ ha/year. Since 1930 , whole-plant, stover and cob yield have increased 1.4, 0.7 and $2.4 \%$ per year respectively (Lauer 2001).

The improved genetic potential of maize silage should come as no surprise. The area of maize planted in the USA in 1999 was 31.6 million hectares (Larson 2001). Given that maize is a hybrid crop and new seed must be purchased each year, the large dollar return to seed companies has enabled the establishment of enormous research programmes that have targeted additional yield and improved agronomic stability as well as quality traits. Pioneer Hi-Bred International alone spends more than \$NZ617 million per annum on maize hybrid research.

Trials conducted on New Zealand farms from Northland to Canterbury during the last six seasons show average maize silage hybrid yields in the range 20-25 t DM/ha (Table 1). Longer maturity hybrids (higher Comparative Relative Maturity $=\mathrm{CRM}$ ) require more heat and take more calendar days from planting to harvest than shorter maturity hybrids, however the yield potential is higher. In fact, the highest yield recorded for Pioneer ${ }^{\circledR}$ brand $33 \mathrm{G} 26$ was $33.37 \mathrm{t}$ $\mathrm{DM} /$ ha in Northland. This indicates the yield potential of a long maturity hybrid under good management and ideal growing conditions.

\section{Advanced management techniques}

There has been a significant improvement in maize silage management techniques over the past 30 years. Planting accuracy has improved with the development of precision planters. The development of insecticide seed treatments has decreased seedling loss from insect damage while reducing the total amount of chemical applied and the risk to the planter operator. There is also a significant number of broad spectrum herbicides registered for use on maize silage crops. In addition, the nutrient requirements of maize silage crops are well documented both for rates and timing-ofapplication. The emergence of large-scale contractors has allowed investment in precision forage harvesters which reduce field losses.

Table 1 Average maize silage hybrid yields in New Zealand (1996-2001 harvest).

\begin{tabular}{|c|c|c|c|c|c|}
\hline $\begin{array}{l}\text { Pioneer }^{\circledR} \text { brand } \\
\text { Hybrid }\end{array}$ & $\mathrm{CRM}^{1}$ & $\begin{array}{c}\text { Number of } \\
\text { years tested }\end{array}$ & $\begin{array}{l}\text { Total number } \\
\text { of sites }\end{array}$ & $\begin{array}{c}\text { Average Yield } \\
\text { (t DM/ha) }\end{array}$ & $\begin{array}{c}\text { Yield Range }{ }^{2} \\
\text { (1 STD) (t DM/ha) }\end{array}$ \\
\hline $38 G 43$ & 87 & 4 & 69 & 20.54 & $17.26-23.81$ \\
\hline 3730 & 100 & 6 & 126 & 21.43 & $18.25-24.62$ \\
\hline $36 \mathrm{H} 36$ & 100 & 3 & 82 & 21.50 & $17.99-25.01$ \\
\hline 3522 & 104 & 5 & 73 & 22.30 & 18.54-26.05 \\
\hline $33 G 26$ & 112 & 3 & 63 & 25.12 & 21.83-28.41 \\
\hline
\end{tabular}

1 Comparative Relative Maturity

${ }^{2}$ STD $=$ Standard deviation 


\section{Maize silage usage in New Zealand}

Livestock Improvement ProfitWatch data for the 1998/ 99 season indicated that $43 \%$ of Waikato dairy farmers were using maize silage, with the majority $(88 \%)$ buying it in (Kolver 2001).

The systems implications of adoption of maize silage by farmers can be represented by scenarios summarised in Tables 2 and 3, and further explained below. It is estimated that around $50 \%$ of the maize silage users are feeding around $250 \mathrm{~kg}$ DM per cow and using maize silage to extend lactation length (Table 2). Through until the mid-1990s, a shortage of farm systems research specifically looking at maize silage integration hampered progress. Farmers evolved a series of systems that showed a stepwise progression in stocking rate and lactation length as the rate of maize silage usage increased (Table 3). A series of trials over four seasons at Waimate West Demonstration Farm, Taranaki, confirmed and refined the principles farmers had developed. Work on this farm during the $1997 / 98$ season was also instrumental in reversing current thinking then which had the greatest response occurring with spring supplementation. It was shown then and since repeated, that autumn feeding gave the greatest milksolids response (up to 170 grams MS $/ \mathrm{kg}$ DM maize silage fed) when compared to spring and summer feeding (Table 3). Responses tend to be higher in the autumn as any pasture that is substituted can be carried forward for 20-60 days to be harvested efficiently either by milking or dry cows.

Once the option of extending lactation has been fully explored, maize silage can be used to increase stocking rate, to fill feed gaps created by earlier calving dates or to fill summer feed deficits. What is emerging, is a pattern of declining response rates to supplementary feeding as the rates of supplement increase e.g., $78 \mathrm{~g}$ $\mathrm{MS} / \mathrm{kg}$ DM being recorded at DRC No2 dairy at a feeding rate of $1247 \mathrm{~kg}$ maize silage/cow (MacDonald 1999).

Currently, the majority of Waikato farmers are using their own farms as "milking platforms" and buying in maize silage for several reasons. Buying in maize silage on a per kilogram DM basis eliminates the DM cost variations associated with varying crop yields and there is no requirement for the dairy farmer to have crop management expertise. Furthermore, every hectare purchased in represents a total drymatter gain of 20-25 t DM whilst a hectare grown on-farm contributes less since the amount of pasture "lost" while the crop is in the ground must be taken into account. In the future, if the current trends of increasing numbers of farmers feeding maize silage and existing users feeding more maize silage per cow continue, maize silage demand may exceed supply and farmers may need to consider growing maize silage on-farm.

\section{Growing maize silage on-farm}

Maize silage can be grown in different paddocks each year as part of a pasture renovation programme. Alternatively, an area of the farm can be set aside for continuous cropping with an annual crop (e.g., Italian ryegrass or winter oats) being planted between successive maize silage crops.

Table $\llbracket 2$ Use of maize silage in pastoral dairying systems (Miller 2000).

\begin{tabular}{lcccc}
\hline $\begin{array}{l}\text { Stocking rate } \\
\text { cows/ha }\end{array}$ & $\begin{array}{c}\text { Maize silage } \\
\text { kg DM/cow }\end{array}$ & Days in milk & $\begin{array}{c}\text { Milksolids } \\
\text { kg/ha }\end{array}$ & $\begin{array}{c}\text { PFS } \\
\text { Percent of } \\
\text { current users }{ }^{2}\end{array}$ \\
\hline 3.0 & 0 & 245 & 950 & 1400 \\
3.0 & 250 & 270 & 1070 & 1550 \\
3.8 & 500 & 270 & 1200 & 1900 \\
4.5 & 1000 & 300 & 1450 & 2200 \\
5.0 & 1250 & 300 & 1600 & 15 \\
\hline
\end{tabular}

${ }^{1}$ Economic Farm Surplus (calculated at $\$ 4.00 / \mathrm{kg}$ milksolids).

${ }^{2}$ Estimate.

Table $₫ 3$ Drymatter yield and milksolids production from systems utilising maize silage grown on-farm.

\begin{tabular}{|c|c|c|c|}
\hline Farm System & $\begin{array}{l}\text { Total } \\
\text { (t DM) }\end{array}$ & $\begin{array}{l}\text { Drymatter yield } \\
\qquad(\text { t DM/ha) }\end{array}$ & $\begin{array}{l}\text { Milksolids per hectare } \\
\text { (kgMS) }\end{array}$ \\
\hline All grass ${ }^{1}$ & 1260000 & 18.0 & 1200 \\
\hline Maize silage + pasture renovation program ${ }^{2}$ & 1392000 & 19.9 & 1326 \\
\hline Maize silage + Italian ryegrass ${ }^{3}$ & 1536257 & 21.9 & 1463 \\
\hline
\end{tabular}




\section{Maize silage as part of a pasture renovation programme}

In this system, poor permanent pasture paddocks are sprayed out in late September and planted in maize silage. The paddock is regrassed into permanent pasture immediately after maize silage harvest in March/April. Assuming a maize silage crop yielding $25 \mathrm{t} \mathrm{DM} / \mathrm{ha}$ and new pasture crop yielding $5 \mathrm{t} \mathrm{DM} / \mathrm{ha}$ in the period April-mid-September, the total drymatter accumulation per hectare would be $30 \mathrm{t} \mathrm{DM} / \mathrm{ha}$. If 11 hectares of a 70-ha farm $(15 \%)$ were planted in maize each year, the average yield per hectare would be increased by $1.9 \mathrm{t} \mathrm{DM}$ allowing a potential production of $1326 \mathrm{~kg}$ MS/ha (Table 3).

Under this system, the whole farm would be regrassed every 7 years. Farmers would benefit from the higher growth rates of newly established swards and genetic gains in pasture yield potential could be realised. This system would be particularly suitable for peat areas that require regular cultivation and incorporation of lime as well as those areas where pastures tend to deteriorate quickly due to insect predation.

\section{Maize silage as part of a continuous cropping programme}

Under this system, a fixed area of the farm would be continually cropped with Italian ryegrass being direct drilled into the maize stubble after the crop is harvested in March/April. The Italian ryegrass would be grazed and/or made into silage and then sprayed out in time for maize planting in October.

Italian ryegrass yields in the period 1 March-1 October could be as high as $8 \mathrm{t} \mathrm{DM} / \mathrm{ha}$. Assuming a $25 \mathrm{t} \mathrm{DM} /$ ha maize silage crop and 11 hectares of a 70ha farm being planted in maize, the average DM production per hectare over the whole farm could be lifted to $21.9 \mathrm{t}$ allowing a potential production of $1463 \mathrm{~kg} \mathrm{MS} /$ ha (Table 3).

There are a number of Waikato farmers who have been continuously cropping maize silage in the same area for several years. One farmer grew maize silage followed by winter oats in the same paddock for 17 years. Soil test information collected over this period would suggest that there was no deterioration in fertility levels (N. Westbury, Genetic Technologies Ltd. pers. comm.). The impacts of a continuous cropping system on the fertility and structure of a range of soil types need to be investigated.

\section{Future options for dairy farms}

There are several maize silage options that may have a place in the New Zealand dairy industry in the future. Many farmers will be content to make use of the opportunities offered by existing maize silage technology. Others are already looking for the next breakthrough. Farmers are exploring the potential to dramatically lift per-cow production by lowering stocking rate and increasing supplement rates, all while trying to maintain profitability. Market signals from GlobalCo are already influencing farmers to alter the pattern of milk supply, with maize silage seen as the only widely available supplement to increase the proportion of milk produced outside the peak months. An area that has only just been tapped is the potential to alter the feed value of maize silage. Refer (Kolver 2001) for discussion on current feed values.

\section{Increased maize silage cutting height}

In a study conducted during the 1999-2000 season, maize silage hybrids were cut at 100, 300 and $600 \mathrm{~mm}$ above ground level. A total of 216 samples were weighed and DM determined. Increasing the cutting height from $100 \mathrm{~mm}$ to $300 \mathrm{~mm}$ increased the DM content by $1.5 \%$ and decreased the yield by $1 \mathrm{t} \mathrm{DM} /$ ha (Table 4). Increasing the cutting height from $100 \mathrm{~mm}$ to $600 \mathrm{~mm}$ increased the DM content by $3.43 \%$ and decreased the yield by $2.52 \mathrm{t} \mathrm{DM} / \mathrm{ha}$.

Lifting the cutter bar to produce higher energy maize silage may be a viable option for those farmers wanting to increase per cow production. It may also have a place where maize silage is being transported large distances.

Table 4 Effect of a range of cutting heights on maize silage yield, energy content and milksolids production potential.

\begin{tabular}{lccc}
\hline & Cutting height $(\mathrm{mm})$ & \\
& 100 & 300 & 600 \\
\hline Silage yield (tDM/ha) & 22.45 & 21.46 & 19.94 \\
Silage drymatter (\%) & 35.73 & 37.22 & 39.16 \\
Energy (MJME/kgDM) & 10.80 & 10.95 & 11.21 \\
Energy per hectare (MJME) & 242460 & 234987 & 223574 \\
Milksolids (\$/ha)* & 10103 & 9791 & 9316 \\
\hline
\end{tabular}

*Assumes a milksolids response of $1 \mathrm{~kg}$ milksolids per 108MJME of maize silage fed and a payout of $\$ 4.50$

\section{Maize earlage or high-moisture corn}

There is a range of energy-dense fermented products that can be made from the maize plant. Maize earlage is made from the cobs (grain and core plus husk covers) of the maize plant harvested at $26-32 \%$ grain moisture (Soderlund 1995). High-moisture corn is made from fermented grain that is harvested at 26$32 \%$ grain moisture using a combine harvester. The energy contents of these feeds are in the range 12.514.5 MJME $/ \mathrm{kgDM}$. 


\section{Narrow row-width maize silage}

Currently, most New Zealand maize silage crops are precision planted in $76.2 \mathrm{~cm}$ rows. Overseas research on the impact of row width on maize silage yield and quality has been inconclusive. During the past season, the Pioneer ${ }^{\circledR}$ brand maize silage research programme evaluated the impact of narrow row-width on the yield and quality of maize silage on a number of New Zealand farms. This research will be repeated during the 2001/2002 growing season. At this stage no data are available.

\section{High-oil maize silage}

There is a huge range of genetic variation within the maize genus. One of the variants being developed is high-oil maize. Normal maize grain has an oil content of around 4\% while high oil hybrids contain over 7\% (Drackley 1998). The greater oil content comes at the expense of starch because the kernels of high-oil maize have a larger germ (embryo) and correspondingly, less endosperm. Studies conducted at the University of Illinois and the US Dairy Forage Research Centre in Wisconsin reported that high-oil maize silage contained $4 \%$ more energy than silage made from a conventional hybrid. However, feeding trials showed that average milk production was the same for cows fed high-oil and conventional maize silage (Drackley 1998). To date all high-oil maize silage feeding trials have been conducted using cows on total mixed rations that contain high levels of concentrates. It may be possible that the response to high-oil maize silage may be higher when animals are on a pasture-based diet and this requires investigation.

\section{REFERENCES}

Deane, T. 1999. The profitable use of supplementary feeds in pasture based dairy farm systems. Proceedings of the Ruakura Farmers' Conference 51: 64-77.

Drackley, J. 1998. High oil corn yields mixed results. pp. 277. In: Hoards Dairyman. April 10, 1998.

Kolver E.S.; Roche J.R,; Miller D.; Densley R. 2001. Maize silage for dairy cows. Proceedings of the New Zealand Grassland Association 63: 195-201.

Livestock Improvement Corporation 2000. Summary of farm production since 1974/75. Dairy Statistics. p. 8.

Larson, W.E.; Cardwell V.B. 2001. History of US Corn Production. http://citv.unl.edu/cornpro/html/ history/history.html.

Lauer, J.G.; Coors, J.G.; Flannery P.J. 2001. Forage Yield and Quality of Corn Cultivars Developed in Different Eras. Crop Science (In press).

MacDonald, K. 1999. Determining how to make inputs increase your economic farm surplus. Proceedings of the Ruakura Farmers' Conference 51: 78-87.

Penno, J. 1999. Identyifying on-farm limitations to profitability. Proceedings of the Ruakura Farmers' Conference 51: 1-9.

Miller, D. 2000. The role and changes in the perception of maize silage in New Zealand pastoral dairy systems. pp. 51-55. In: Proceedings of the New Zealand Maize Conference, Foundation for Arable Research, Hamilton.

Soderlund, S. 1995. Feeding value of High Moisture Corns. In: Forage Advisor Update, Pioneer HiBred International Inc. 